\title{
L-selenomethionine modulates high LET radiation-induced alterations of gene expression in cultured human thyroid cells
}

\author{
JELENA STEWART ${ }^{1}$, JEFFREY WARE $^{1}$, PAOLO FORTINA ${ }^{2}$, \\ JIM BREAUX $^{3}$, SANDEEP GULATI $^{3}$ and ANN KENNEDY ${ }^{1}$
}

\author{
${ }^{1}$ Department of Radiation Oncology, University of Pennsylvania School of Medicine, 195 John Morgan Building, \\ 3620 Hamilton Walk, Philadelphia, PA 19104-6072; ${ }^{2}$ Center for Translational Medicine, Thomas Jefferson University, \\ 1025 Walnut Street, Philadelphia, PA 19107; ${ }^{3}$ ViaLogy Corp., 2400 Lincoln Avenue, Altadena, CA 91001, USA
}

Received September 7, 2005; Accepted October 20, 2005

\begin{abstract}
L-selenomethionine (SeM) is emerging as a highly effective protective agent against radiation-induced biological effects. We have shown its protective effect on space radiationinduced death of MCF-10 cells as well as on space radiationinduced transformation of HTori-3 cells. The present study was aimed at elucidation of molecular mechanisms and cellular pathways involved in SeM-mediated radioprotection. Human thyroid epithelial cells (HTori-3 cells), in the presence or absence of SeM, were exposed to a non-toxic or a slightly toxic radiation dose from $1 \mathrm{GeV} / \mathrm{n}$ iron ions $(10 \mathrm{cGy}$ and 20 cGy, respectively). Total RNA was prepared and changes in gene expression were analyzed using microarray technology. Our analysis has revealed a dramatic effect of SeM on alterations of gene expression caused by space radiation. This study provides a basis for furthering our knowledge about radiation-induced molecular and cellular changes that lead to cellular transformation and death.
\end{abstract}

\section{Introduction}

This report reflects our ongoing investigation into the mechanisms involved in radiation-induced transformation in vitro and the suppression of radiation-induced malignant transformation in vitro by SeM. The epidemiological and experimental evidence describing ionizing radiation-induced cancer is abundant $(1,2)$. Our daily exposure to background doses of ionizing radiation comes from naturally occurring radioactivity from cosmic rays as well as from radionuclides present in the ground, food, water and building materials. Only occasionally are we exposed to significant doses of

Correspondence to: $\mathrm{Dr}$ Ann R. Kennedy, University of Pennsylvania School of Medicine, 195 John Morgan Building, 3620 Hamilton Walk, Philadelphia, PA 19104-6072, USA

E-mail: akennedy@mail.med.upenn.edu

Key words: L-selenomethionine, gene expression, ionizing radiation, malignant transformation radiation from man-made sources; the main contribution of this source comes from medical treatments. On the other hand, while traveling on space missions, astronauts are exposed to ionizing radiations from an array of particles never encountered on earth due to the shielding effect of the Earth's magnetic field. Of particular importance is radiation from high energy and high atomic number (HZE) particles. Radiation from HZE particles has high linear energy transfer (LET) and, therefore, is considered to be highly effective in causing biological damage. Modification of radiation-induced malignant transformation has been a focus of our research. Studies such as ours advance the concept that radiation-induced malignant transformation or carcinogenesis is not an inevitable progression and can be stopped by the use of non-toxic, noncarcinogenic agents.

Current efforts, focused on the prevention of radiationinduced carcinogenesis in this laboratory, have utilized HTori-3 cells, a human thyroid cell transformation system originally developed by Lemoine et al (3) and adapted for studies of radiation transformation by Riches et al (4). HTori-3 cells can be transformed by HZE particle radiation (5), and Lselenomethionine (SeM) can prevent HZE particle-induced transformation in HTori-3 cells (5). In both in vivo and in vitro studies, SeM has emerged as one of the most potent agents evaluated as a countermeasure for HZE particle-induced oxidative stress (5). Non-toxic levels of SeM have been shown to have cancer chemopreventive activity (6-10). SeM is the form of selenium that has been chosen by the National Cancer Institute (NCI) for current studies of selenium as a cancer preventive agent. The largest intervention study using SeM as the cancer preventive agent is a phase-III prostate cancer prevention trial known as the Selenium and Vitamin E Cancer Prevention Trial (11).

The research discussed in this report concerns mechanisms of radiation-induced malignancy and was driven by our hypothesis that radiation is capable of starting an ongoing cellular process (by a high frequency, epigenetic event) that is characterized by a state of genetic instability; a later event or events, presumably genetic, then lead directly to malignant transformation $(12,13)$. The assumptions are that the heritable epigenetic event is a change in gene expression induced by radiation exposure and that $\mathrm{L}$-selenomethionine is capable of 
Table I. Description of the treatment groups.

\begin{tabular}{lcc}
\hline Treatment group & $5 \mu$ M SeM & Radiation dose (cGy) \\
\hline CT0 & No & 0 \\
CT10 & No & 10 \\
CT20 & No & 20 \\
SEM0 & Yes & 0 \\
SEM10 & Yes & 10 \\
SEM20 & Yes & 20 \\
\hline
\end{tabular}

preventing, suppressing or reversing this change in gene expression. We have used microarray technology to assess the effects of SeM on HZE particle radiation-induced changes in gene expression. HTori-3 cells were exposed to either a non-toxic radiation dose of $10 \mathrm{cGy}$ from iron ions or to a slightly toxic radiation dose of $20 \mathrm{cGy}$ from iron ions. For both radiation doses, SeM had a profound effect on radiationinduced gene regulation.

\section{Materials and methods}

Cell culture and treatment with SeM. HTori-3 cells, a human thyroid epithelial cell line, were maintained in DMEM medium (Gibco, Invitrogen) supplemented with $1 \%$ glutamine and $10 \%$ fetal bovine serum (Atlanta Biologicals). Twenty-four hours prior to radiation exposure, the medium was either supplemented with $5 \mu \mathrm{M}$ L-selenomethionine or it was supplement free. At the time of radiation exposure, the cells were confluent.

Exposure to high LET radiation. Exposure to HZE particles was performed at the NASA Space Radiation Laboratory (NSRL) Facility at the Brookhaven National Laboratory, Upton, New York. Cells were exposed to 0,10 or $20 \mathrm{cGy}$ of $1.0 \mathrm{GeV} / \mathrm{n}$ radiation from iron ions.

RNA preparation and microarray hybridization. Six hours post-irradiation, the cells were frozen in denaturing solution (Totally RNA, Ambion) and transported to the University of Pennsylvania, where further steps for isolation of total RNA were taken according to the manufacturer's instructions. Each microarray probe was prepared using $15 \mu \mathrm{g}$ of total RNA. First-strand cDNA was synthesized using Superscript II reverse transcriptase (Life Technologies). Following RNA degradation with RNase $\mathrm{H}$ and second-strand cDNA synthesis with DNA polymerase I, double-stranded cDNA was extracted using phenol:chloroform:isoamyl alcohol $=25: 24: 1(\mathrm{v} / \mathrm{v})$. The double-stranded cDNA template was transcribed and labeled with biotin in vitro (IVTA, Enzo Biochem). The resulting cRNA was fragmented and hybridized to U133A Gene Chips (Affymetrix) according to the manufacturer's instructions.

Signal processing and analysis. Gene-level expression values were generated from scanned images (DAT files) using the ViaLogy microarray analysis service (VMAxS, http://www.

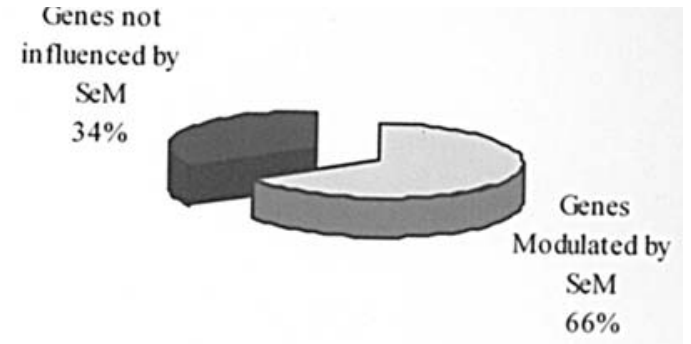

Figure 1. Genes up-regulated by a 10-cGy radiation dose from iron ions.

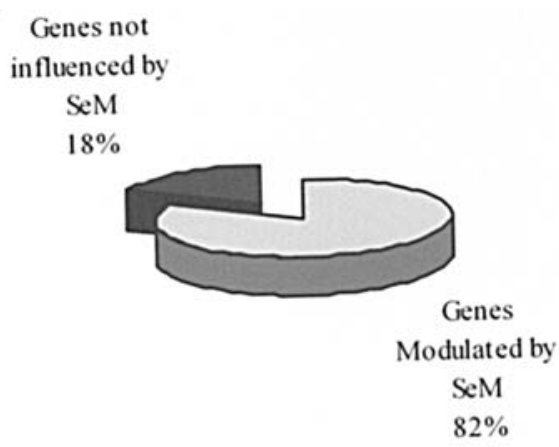

Figure 2. Genes down-regulated by a $10-\mathrm{cGy}$ radiation dose from iron ions.

vialogy.com/). Gene-level expression values from all 12 microarrays were then quantile normalized (14). Genes differentially expressed as a result of a given treatment were selected as follows. For each gene, four ratios were computed from the replicate hybridizations: treated-A:untreated-A, treated-A:untreated-B, treated-B:untreated-A, and treated$\mathrm{B}$ :untreated-B. The ratios were $\log 2$-transformed and then a score was calculated for each gene using the following formula:

$$
\text { score }=\frac{\overline{r_{i}} \sqrt{n_{i}}}{s_{i}+0.5}
$$

where $n_{i}$ is the number of finite log-ratios computed for gene $i$ (if $n_{i}<2$, a score was not computed), $r_{i}$ is the mean of the $n_{i}$ $\log$-ratios, and $s_{i}$ is the standard deviation of the log-ratios. The genes with the top 300 Iscorel were selected for further study. EASE over-representation analysis (15) was used to test for Gene Ontology classes that occurred more frequently in a list of genes of interest, significantly regulated genes, than would be expected by chance given the prevalence of a class among all genes assayed.

\section{Results}

Monolayer cultures of HTori-3 cells, supplemented with $5 \mu \mathrm{M}$ $\mathrm{SeM}$ or in non-supplemented medium, were exposed to a 10 - or $20-\mathrm{cGy}$ radiation dose from $1 \mathrm{GeV} / \mathrm{n}$ iron ions. The cultures were maintained for an additional $6 \mathrm{~h}$ post-irradiation, and subsequently trypsinized for preparation of total RNA. Microarray technology was used to analyze changes in gene expression for the 5 treatment groups (Table I) compared to the non-treated group, CT0. To establish the significance of the effect of SeM supplementation on gene expression in irradiated cells, lists of significantly regulated genes were 


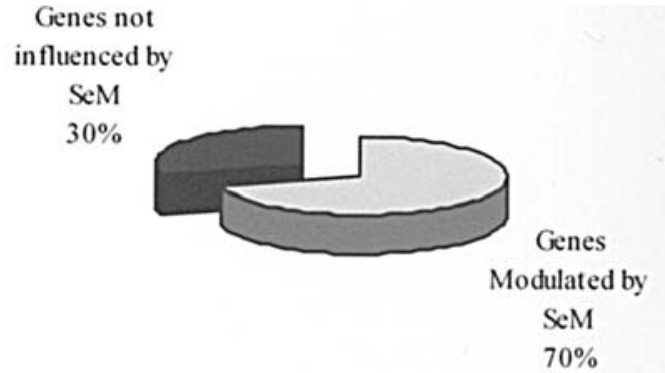

Figure 3. Genes up-regulated by a 20-cGy radiation dose from iron ions.

compared for the shared features. The results of the SEM10 versus CT10 and SEM20 versus CT20 comparisons are shown as pie diagrams in Figs. 1-4. Supplementation with SeM appears to have a profound effect on HZE radiation-induced alterations of gene expression. In HTori-3 cells exposed to a 10 -cGy dose of radiation from iron ions, supplementation with SeM modified the differential expression of $66 \%$ of up-regulated genes (Fig. 1), and $82 \%$ of down-regulated genes (Fig. 2). Similarly, in cells exposed to a 20-cGy dose of radiation from iron ions, supplementation with SeM modified the differential expression of $70 \%$ of up-regulated genes (Fig. 3) and 93\% of down-regulated genes (Fig. 4). Collectively, these results indicate a large-scale effect of SeM supplementation on regulation of gene expression in HTori-3 cells irradiated with low doses of high LET radiation.

HZE radiation-regulated gene expression which was modifiable by SeM was further analyzed using EASE overrepresentation analysis. EASE analysis tests for Gene Ontology classes that occur more frequently in a list of genes of interest than would be expected by chance given the prevalence of a class among all genes assayed. The results of

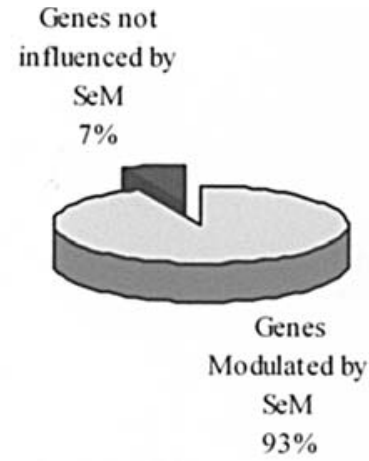

Figure 4. Genes down-regulated by a 20-cGy radiation dose from iron ions

the EASE over-representation analysis indicated that, in HTori-3 cells exposed to a 10 -cGy radiation dose from iron ions, SeM abolishes the up-regulation of various structural molecules, including collagen, and molecules with transcription regulator activity (Table II). For the same radiation dose, radiation-induced down-regulation of some components of the ribonucleoprotein complex is modified by SeM (Table III). In HTori-3 cells exposed to a 20-cGy radiation dose from iron ions, SeM abolishes the down-regulation of a significant number of regulators of the cell cycle, including nuclear division components, as well as of molecules involved in transcription from the Pol II promoter (Table IV).

A further analysis using EASE software included significantly regulated genes in HTori-3 cells irradiated in the presence of SeM that were not significantly regulated by $\mathrm{SeM}$ alone or by radiation alone. Table $\mathrm{V}$ shows that upregulated genes specific for SEM10 are involved in the negative regulation of cell proliferation and the response to an external stimulus. Also, down-regulated genes specific for

Table II. Over-representation analysis of genes up-regulated by a 10-cGy radiation dose from iron ions in the absence of SeM (CT10) but not in the presence of SeM (SEM10).

\begin{tabular}{|c|c|c|c|c|c|}
\hline Gene category & $\begin{array}{l}\text { List } \\
\text { Hits }\end{array}$ & $\begin{array}{l}\text { List } \\
\text { Total }\end{array}$ & $\begin{array}{c}\text { Population } \\
\text { Hits }\end{array}$ & $\begin{array}{c}\text { Population } \\
\text { Total }\end{array}$ & $\begin{array}{l}\text { EASE } \\
\text { score }\end{array}$ \\
\hline Collagen & 4 & 104 & 32 & 10787 & 0.0034297 \\
\hline Structural molecule activity & 15 & 105 & 694 & 11065 & 0.0053189 \\
\hline Transcription regulator activity & 19 & 105 & 1057 & 11065 & 0.0092204 \\
\hline Nucleobase, nucleoside, nucleotide and nucleic acid metabolism & 38 & 108 & 2673 & 10937 & 0.0115827 \\
\hline Transcription & 28 & 108 & 1818 & 10937 & 0.0146818 \\
\hline Extracellular matrix & 8 & 104 & 287 & 10787 & 0.0198599 \\
\hline Collagen type VI & 2 & 104 & 3 & 10787 & 0.0283755 \\
\hline Transcription, DNA-dependent & 26 & 108 & 1756 & 10937 & 0.0306572 \\
\hline Protein binding & 22 & 105 & 1495 & 11065 & 0.0366783 \\
\hline Regulation of transcription & 25 & 108 & 1704 & 10937 & 0.0382372 \\
\hline Nucleoside transport & 2 & 108 & 4 & 10937 & 0.0385679 \\
\hline Cell adhesion & 11 & 108 & 542 & 10937 & 0.0391736 \\
\hline Nucleoside transporter activity & 2 & 105 & 5 & 11065 & 0.0461281 \\
\hline Extracellular matrix structural constituent & 4 & 105 & 88 & 11065 & 0.0498686 \\
\hline
\end{tabular}


Table III. Over-representation analysis of genes down-regulated by a 10-cGy radiation dose from iron ions in the absence of SeM (CT10) but not in the presence of SeM (SEM10).

\begin{tabular}{lccccc}
\hline Gene category & $\begin{array}{c}\text { List } \\
\text { Hits }\end{array}$ & $\begin{array}{c}\text { List } \\
\text { Total }\end{array}$ & $\begin{array}{c}\text { Population } \\
\text { Hits }\end{array}$ & $\begin{array}{c}\text { Population } \\
\text { Total }\end{array}$ & $\begin{array}{c}\text { EASE } \\
\text { score }\end{array}$ \\
\hline Cytosolic large ribosomal subunit & 4 & 50 & 37 & 10787 & 0.000614 \\
Large ribosomal subunit & 4 & 50 & 48 & 10787 & 0.0013197 \\
Cytosol & 8 & 50 & 384 & 10787 & 0.00162 \\
Cytosolic ribosome & 4 & 50 & 66 & 10787 & 0.0032973 \\
RNA binding & 7 & 54 & 465 & 11065 & 0.0230436 \\
Binding & 39 & 54 & 6414 & 11065 & 0.0275012 \\
Ribonucleoprotein complex & 6 & 50 & 420 & 10787 & 0.0409512 \\
\hline
\end{tabular}

Table IV. Over-representation analysis of genes down-regulated by a 20-cGy radiation dose from iron ions in the absence of SeM (CT20) but not in the presence of SeM (SEM20).

\begin{tabular}{|c|c|c|c|c|c|}
\hline Gene category & $\begin{array}{l}\text { List } \\
\text { Hits }\end{array}$ & $\begin{array}{l}\text { List } \\
\text { Total }\end{array}$ & $\begin{array}{c}\text { Population } \\
\text { Hits }\end{array}$ & $\begin{array}{l}\text { Population } \\
\text { Total }\end{array}$ & $\begin{array}{l}\text { EASE } \\
\text { score }\end{array}$ \\
\hline Nuclear division & 7 & 92 & 151 & 10937 & 0.0015932 \\
\hline M phase & 7 & 92 & 157 & 10937 & 0.0019421 \\
\hline Mitosis & 6 & 92 & 121 & 10937 & 0.0033264 \\
\hline M phase of mitotic cell cycle & 6 & 92 & 123 & 10937 & 0.003569 \\
\hline Cell cycle & 14 & 92 & 690 & 10937 & 0.0044856 \\
\hline Cell proliferation & 18 & 92 & 1036 & 10937 & 0.0047559 \\
\hline Mitotic cell cycle & 9 & 92 & 329 & 10937 & 0.0059962 \\
\hline ATP dependent helicase activity & 5 & 96 & 102 & 11065 & 0.0114239 \\
\hline Transcription from Pol II promoter & 10 & 92 & 454 & 10937 & 0.0130361 \\
\hline Helicase activity & 5 & 96 & 117 & 11065 & 0.0180933 \\
\hline Obsolete cellular component & 9 & 91 & 433 & 10787 & 0.0278196 \\
\hline Chromatin remodeling & 3 & 92 & 32 & 10937 & 0.028891 \\
\hline Non-covalent chromatin modification & 3 & 92 & 32 & 10937 & 0.028891 \\
\hline Nucleus & 32 & 91 & 2748 & 10787 & 0.0358544 \\
\hline Metabolism & 60 & 92 & 6063 & 10937 & 0.0430717 \\
\hline Physiological process & 82 & 92 & 8954 & 10937 & 0.0445714 \\
\hline
\end{tabular}

Table V. Over-representation analysis of genes up-regulated by a 10-cGy radiation dose from iron ions in the presence of SeM (SEM10) but not in the presence of SeM only (SEM0) or by a 10-cGy radiation dose only (CT10).

\begin{tabular}{lcccccc}
\hline Gene category & List & List & Population & Population \\
Hits & Total & $\begin{array}{c}\text { EASE } \\
\text { score }\end{array}$ & $\begin{array}{c}\text { Fisher } \\
\text { exact }\end{array}$ \\
\hline Negative regulation of cell proliferation & 5 & 83 & 113 & 7825 & 0.0305 \\
Response to external stimulus & 18 & 83 & 1033 & 7825 & 0.00683 \\
\hline
\end{tabular}

SEM10 are components of the Golgi apparatus and a significant number are involved in regulation of transcription (Table VI). Interestingly, significant numbers of up-regulated genes specific for SEM20 have roles in the cell cycle and proliferation as well as apoptosis (Table VII). Significant numbers of down-regulated genes specific for SEM20 are 
Table VI. Over-representation analysis of genes down-regulated by a 10-cGy radiation dose from iron ions in the presence of SeM (SEM10) but not in the presence of SeM only (SEM0) or by a 10-cGy radiation dose only (CT10).

\begin{tabular}{|c|c|c|c|c|c|c|}
\hline Gene category & $\begin{array}{l}\text { List } \\
\text { Hits }\end{array}$ & $\begin{array}{l}\text { List } \\
\text { Total }\end{array}$ & $\begin{array}{c}\text { Population } \\
\text { Hits }\end{array}$ & $\begin{array}{c}\text { Population } \\
\text { Total }\end{array}$ & $\begin{array}{l}\text { EASE } \\
\text { score }\end{array}$ & $\begin{array}{l}\text { Fisher } \\
\text { exact }\end{array}$ \\
\hline Golgi apparatus & 3 & 17 & 243 & 7038 & 0.104 & 0.0193 \\
\hline Transcription regulator activity & 4 & 14 & 859 & 8126 & 0.151 & 0.0524 \\
\hline
\end{tabular}

Table VII. Over-representation analysis of genes up-regulated by a 20-cGy radiation dose from iron ions in the presence of SeM (SEM20) but not in the presence of SeM only (SEM0) or by a 20-cGy radiation dose only (CT20).

\begin{tabular}{|c|c|c|c|c|c|c|}
\hline Gene category & $\begin{array}{l}\text { List } \\
\text { Hits }\end{array}$ & $\begin{array}{l}\text { List } \\
\text { Total }\end{array}$ & $\begin{array}{c}\text { Population } \\
\text { Hits }\end{array}$ & $\begin{array}{l}\text { Population } \\
\text { Total }\end{array}$ & $\begin{array}{l}\text { EASE } \\
\text { score }\end{array}$ & $\begin{array}{l}\text { Fisher } \\
\text { exact }\end{array}$ \\
\hline Cell proliferation & 18 & 90 & 816 & 7825 & 0.00962 & 0.00478 \\
\hline Cell cycle & 13 & 90 & 542 & 7825 & 0.0192 & 0.00868 \\
\hline Nucleus & 33 & 81 & 2079 & 7038 & 0.0286 & 0.0199 \\
\hline Apoptosis & 9 & 90 & 330 & 7825 & 0.0336 & 0.0132 \\
\hline Programmed cell death & 9 & 90 & 331 & 7825 & 0.0341 & 0.0135 \\
\hline Cell death & 9 & 90 & 351 & 7825 & 0.0456 & 0.0191 \\
\hline Death & 9 & 90 & 353 & 7825 & 0.0469 & 0.0197 \\
\hline Structural constituent of cytoskeleton & 4 & 97 & 75 & 8126 & 0.0587 & 0.0122 \\
\hline Regulation of transcription & 20 & 90 & 1161 & 7825 & 0.0611 & 0.0385 \\
\hline
\end{tabular}

Table VIII. Over-representation analysis of genes down-regulated by a 20-cGy radiation dose from iron ions in the presence of SeM (SEM20) but not in the presence of SeM only (SEM0) or by a 20-cGy radiation dose only (CT20).

\begin{tabular}{lcccccc}
\hline Gene category & $\begin{array}{c}\text { List } \\
\text { Hits }\end{array}$ & $\begin{array}{c}\text { List } \\
\text { Total }\end{array}$ & $\begin{array}{c}\text { Population } \\
\text { Hits }\end{array}$ & $\begin{array}{c}\text { Population } \\
\text { Total }\end{array}$ & $\begin{array}{c}\text { EASE } \\
\text { score }\end{array}$ & $\begin{array}{c}\text { Fisher } \\
\text { exact }\end{array}$ \\
\hline Vesicle-mediated transport & 4 & 25 & 194 & 7825 & 0.0207 & 0.00308 \\
Transferase activity & 8 & 26 & 974 & 8126 & 0.0239 & 0.00892 \\
Transferring phosphorus-containing groups & 6 & 26 & 584 & 8126 & 0.0301 & 0.00894 \\
Protein amino acid phosphorylation & 5 & 25 & 395 & 7825 & 0.0305 & 0.00735 \\
Protein kinase activity & 5 & 26 & 404 & 8126 & 0.0332 & 0.0082 \\
Phosphorylation & 5 & 25 & 424 & 7825 & 0.0382 & 0.00985 \\
\hline
\end{tabular}

involved in vesicle-mediated transport and some act as protein kinases (Table VIII).

\section{Discussion}

Ionizing radiation-induced adverse biological effects, such as death and transformation of cells, have been extensively documented. Of particular concern for the health of astronauts during extended space travel is radiation from HZE particles, which has been shown to increase oxidative stress both in vivo and in vitro, as well as cytotoxicity and cell transformation in vitro (5). SeM has emerged as a potentially useful countermeasure against space radiation-induced adverse biological effects. To explore the molecular mechanisms involved in the protective effects of SeM, we have used microarray technology to examine changes in gene expression in HTori-3 cells irradiated with $1 \mathrm{GeV} / \mathrm{n}$ of iron ions in the presence or absence of selenomethionine.

Changes in gene expression were evaluated in irradiated HTori-3 cells in the absence of SeM (the CT10 and CT20 treatment groups), and in the presence of SeM (the SEM10 and SEM20 treatment groups). A striking difference in radiation-induced gene expression is apparent between SeM-supplemented and -unsupplemented HTori-3 cells. Supplementation with SeM modified the differential expression of $66 \%$ of up-regulated and $82 \%$ of down-regulated genes in 
cells exposed to a 10-cGy radiation dose from iron ions, as well as $70 \%$ of up-regulated and $93 \%$ of down-regulated genes in cells exposed to a $20-\mathrm{cGy}$ radiation dose from iron ions. The large-scale effect of SeM on radiation-induced regulation of gene expression could have two explanations. SeM plays a major role in antioxidant activities in cells, and part of its action may be due to a scavenging effect, whereby the effective radiation dose reaching cells and eventually causing damage within cells would be significantly reduced. The scavenging effect, however, can not account for the regulation of genes specific for cells irradiated in the presence of SeM but were not differentially regulated in cells that were only supplemented with SeM or only irradiated.

The other mode of action that could explain a large shift in differentially expressed genes would be through modification of one or more transcription regulator activities. From the data presented in this report, a large shift in the expression of various regulators of transcription is evident in irradiated cells when SeM is present. In cells exposed to a non-toxic dose of radiation from HZE particles (10 cGy), the expression of a significant number $(\mathrm{p}<0.01)$ of genes involved in the regulation of transcription is up-regulated. In the presence of SeM, however, expression of these genes is not altered upon irradiation with a 10 -cGy radiation dose from iron ions. Moreover, a different set of genes involved in regulation of transcription are down-regulated when cells are irradiated with the same dose from iron ions and in the presence of SeM. The present study in HTori-3 cells also indicates that, in cells exposed to a $20-c G y$ radiation dose from iron ions, SeM supplementation leads to modulation of transcriptional regulation of a significant number of genes involved in the cell cycle, proliferation and death. Future studies will be performed to determine whether this SeM-mediated modulation at the transcriptional level leads to protection against radiationinduced killing.

The results presented here suggest that the mechanism(s) underlying the protective effects of SeM against radiationinduced cell killing and transformation, as well as malignant transformation, can be explored at the level of transcriptional regulation. Our future studies will focus on mechanisms by which ionizing radiation induces transformation of cells. We believe that the use of SeM as a countermeasure will help us to identify molecular targets which are key players in events leading to the malignant transformation of cells.

\section{References}

1. National Research Council, Committee on the Biological Effects of Ionizing Radiations: Health Effects of Exposure to Low Levels of Ionizing Radiation, BEIR V. National Academy Press: Washington, DC, 1990.

2. United Nations Scientific Committee on the Effects of Atomic Radiation: Sources and Effects of Ionizing Radiation. UNSCEAR 2000 Report to the General Assembly, with Scientific Annexes. United Nations: New York, 2000.

3. Lemoine NR, Mayall ES, Jones T, Sheer D, McDermid S, Kendall-Taylor P and Wynford-Thomas D: Characteristics of human thyroid epithelial cells immortalized in vitro by simian virus 40 DNA transfection. Br J Cancer 60: 897-903, 1989.

4. Riches AG, Herceg Z, Bryant PE and Wynford-Thomas D: Radiation-induced transformation of SV40-immortalized human thyroid epithelial cells by single and fractionated exposure to gamma-irradiation in vitro. Intl J Radiat Biol 66: 757-765, 1994.

5. Kennedy AR, Ware JH, Guan J, Donahue JJ, Biaglow JE, Zhou Z, Stewart JA, Vazquez M and Wan XS: Selenomethionine protects against adverse biological effects induced by space radiation. Free Radic Biol Med 36 (2): 259-266, 2004.

6. Li JY, Taylor PR, Li B, Dawsey S, Wang GQ, Ershow AG, Guo W, Liu SF and Yanglast CS: Nutrition intervention trials in Linxian, China: supplementation with specific vitamin/mineral combinations, cancer incidence, and disease-specific mortality among adults with esophageal dysplasia. J Natl Cancer Inst 85: 1492-1498, 1993.

7. Reddy BS, Rivenson A, El-Bayoumy K, Upadhyaya P, Pittman B and Rao CV: Chemoprevention of colon cancer by organoselenium compounds and impact of high- or low-fat diets. J Natl Cancer Inst 89: 506-512, 1997.

8. Nelson MA, Porterfield BW, Jacobs ET and Clark LC: Selenium and prostate cancer prevention. Semin Urol Oncol 17: 91-96, 1999.

9. Khuri FR and Lippman SM: Lung cancer chemoprevention. Semin Surg Oncol 19: 100-105, 2000.

10. Clark LC, Combs GF Jr, Turnbull BW, Slate EH, Chalker DK, Chow J, Davis LS, Glover RA and Grahamlast GF: Effects of selenium supplementation for cancer prevention in patients with carcinoma of the skin. A randomized controlled trial. JAMA 276: 1957-1963, 1996.

11. Klein EA, Thompson IM, Lippman SM, Goodman PJ, Albanes D, Taylor PR and Coltman C: SELECT: the next prostate prevention trial. Selenium and Vitamin E Cancer Prevention Trial. J Urol 166: 1311-1315, 2001.

12. Kennedy AR, Fox M, Murphy G, Little JB: Relationship between $x$-ray exposure and malignant transformation in C3H10T1/2 cells. Proc Natl Acad Sci USA 77: 7262-7266, 1980 .

13. Kennedy AR, Cairns J and Little JB: Timing of the steps in transformation of C3H10T1/2 cells by x-irradiation. Nature 307: 85-86, 1984.

14. Bolstad BM, Irizarry RA, Astrand M and Speed TP: A comparison of normalization methods for high density oligonucleotide array data based on variance and bias. Bioinformatics 19 (2): 185-193, 2003.

15. Hosack DA, Dennis G Jr, Sherman BT, Lane HC and Lempicki RA: Identifying biological themes within lists of genes with EASE. Genome Biol 4 (10): R70, 2003. 